\title{
AGRICULTURAL LAND USE CHANGE ANALYSIS USING REMOTE SENSING AND GIS: A CASE STUDY OF ALLAHABAD, INDIA
}

\author{
V. Kumar ${ }^{1, *}$, S. Agrawal ${ }^{2, *}$ \\ ${ }^{1}$ GIS Cell, Motilal Nehru National Institute of Technology Allahabad, Prayagraj-211004, U.P., India - vgupta491@gmail.com \\ ${ }^{2}$ GIS Cell, Motilal Nehru National Institute of Technology Allahabad, Prayagraj-211004, U.P., India - sonam@mnnit.ac.in
}

\section{Commission III, WG III/10}

KEY WORDS: Agriculture, LULC, Classification, Change detection, Landsat, GIS

\begin{abstract}
:
Urbanization is occurring at a fast rate in India. Population residing in urban areas was $11.4 \%$ according to the Census of 1901 . This percentage has gradually increased to $31.16 \%$ according to the Census of 2011 . Conversion of agricultural land into non-agricultural uses is the major side effect of urbanization. The objective of this paper is to identify the changes in the agriculture land and its conversion into other Land Use Land Cover (LULC) type. In order to achieve this objective, mapping of land use changes is done by using the GIS and remote sensing. This study utilizes satellite images along with field survey and statistical data to detect the change of farming land into other LULC type in different tehsils of Allahabad district. This study is carried out over the time period of 18 years that ranges from 2000 to 2018. This work provides the detail of expansion and shrinkage of agriculture and open land at tehsil level. Landsat data is used in this work which is open source and freely downloadable. Landsat images of study period i.e. from 2000 to 2018 are downloaded and then preprocessed. Supervised classification of images is performed using Gaussian maximum likelihood technique. The training samples are collected with the help of ground truth information. After this, identification of land use changes is done on pixel by pixel basis. This would find out the LULC class which is primary responsible for the shrinkage of agriculture land. This spatio-temporal and statistical research work will help to construct a base for a sustainable development model.
\end{abstract}

\section{INTRODUCTION}

Indian economy majorly depends upon the agriculture. India is considered as the agricultural country (Brien et al., 2004). Here the agriculture is continuously facing challenges because of climate change, crop diseases, insufficient irrigation and volatile market (Bhan and Behera, 2014). Agricultural land loss is a global problem (Ghar et al., 2007). In order to preserve nature and ensure output the sustainable agriculture concept has been given (Mendas and Delali, 2012).

GIS and remote sensing can be used to support the agriculture. Several papers were found where these techniques are utilised in agriculture. Some of these are discussed here. Ray and Dadhwal (2001) have applied remote sensing and GIS to compute evapotranspiration in disease free crops. Some researchers have utilised satellite imagery for land suitability assessment for agriculture which is a very essential feature for agriculture development and future planning (Abdelrahman et al., 2016; Bandyopadhyay et al., 2009). Panigrahy et al.(2005) used the temporal and multisensory data to obtain the crop related indices that predict the crop rotation, pattern and production. Other applications of GIS and remote sensing in the field of agriculture are land capability evaluation, assessment of crop damage and crop management (Huang et al., 2018; Kabanda, 2015).

Land Use Land Cover (LULC) informs the type of human activity or natural cover present at a particular location (Kassawmar et al., 2016). Temporal LULC class change models are very useful to assesses the causes and pattern of land use change (Lin et al., 2008). LULC classification is used in various applications that can be related to agriculture (Gibril et al., 201s6), environment (Jiang et al., 2015) and urban growth (Wang and Maduako, 2018).
Remote sensing provides satellite data on which LULC studies are performed (Jiang et al., 2015). Change detection in LULC of any geographic location by using multi-temporal satellite imagery helps in understanding landscape dynamics (Rawat and Kumar, 2015). Conversion of agricultural land into nonagricultural use is the major problem of urbanization (Fazal, 2000). Classification of satellite image is used for converting the image into LULC map. It is the way for allocating pixels to particular classes. Pixel is an individual unit made out of values in several spectral bands ( Lillisand et al., 2004).

There are many satellite missions launched by different countries which are used for research works but only some of them are freely available. Landsat images are used in this work. They are open source and freely downloadable (Hu et al., 2016). Landsat data are used in LULC change studies because of the continuous availability of images (Hansen and Loveland, 2012). It is consistently providing the images that are commonly used in identification of global LULC change since 1972 (Williams et al., 2006).

The present study has been taken to understand the changes in agriculture and open land in Allahabad district from the years 2000 to 2018 . The objective this study is to identify the changes in the agriculture and open land along with its conversion into other LULC types. For this the mapping of land use changes is done with the help of GIS and remote sensing. It would provide the details of expansion or shrinkage of agriculture and open land.

\section{STUDY AREA AND DATASETS}

Study area of the present work is Allahabad district of Uttar Pradesh as shown in Figure 1. Allahabad is recently renamed as Prayagraj. The geographical extent of the study area is from

\footnotetext{
${ }^{*}$ Corresponding Authors
} 
$81.5^{\circ} \mathrm{E}$ to $82.5^{\circ} \mathrm{E}$ longitude and from $24.8^{\circ} \mathrm{N}$ to $25.8^{\circ} \mathrm{N}$ latitude Its total area is $5,482 \mathrm{~km}^{2}$. This region falls in the lower IndoGangetic plains and Ganga-Yamuna Doab. This place is extremely suitable for agriculture because of high soil fertility and topography. As per Census of 2011, total population in this region is $59,54,391$ with population density of 1,086 persons per $\mathrm{km}^{2}$. This makes Allahabad the most populous district in Uttar Pradesh. There are total eight tehsils in Allahabad district which are Karchhana, Koraon, Phulpur, Bara, Meja, Allahabad, Soraon and Handia. The high population growth rate resulted in the LULC type conversion and resource exploitation.

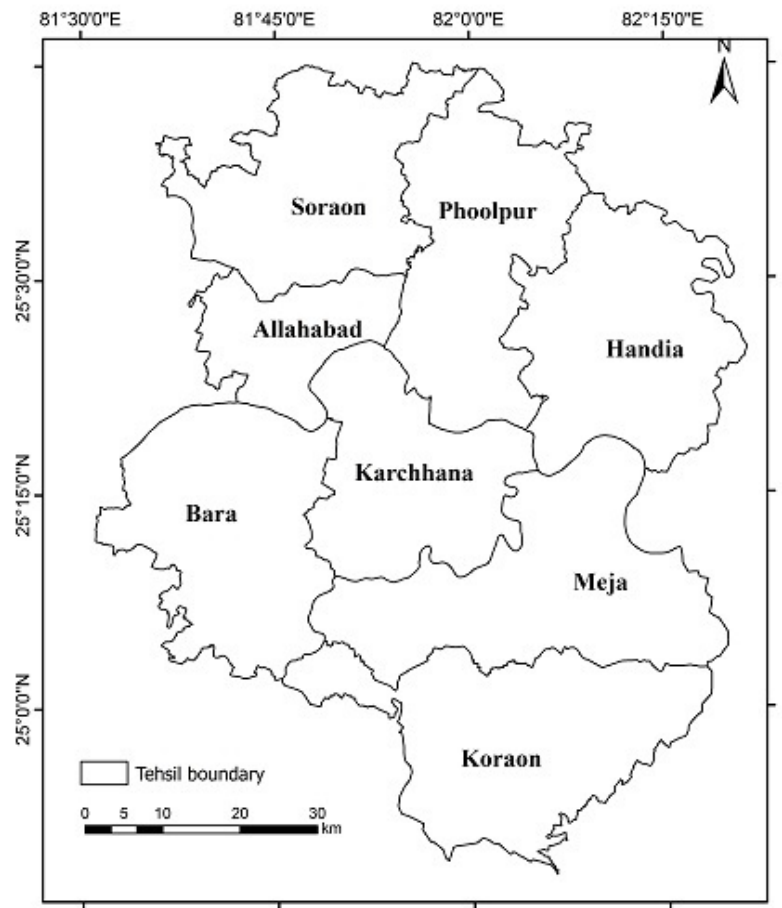

Figure 1. Study area map showing Allahabad district with tehsil boundary of all eight tehsils.

Landsat satellite images are used in this work which are open source and freely downloadable. As per available data, images of Landsat Enhanced Thematic Mapper plus (ETM+), Thematic Mapper (TM), and Operational Land Imager (OLI) sensors are used for 2000, 2010 and 2018 respectively. The spatial resolution of images is $30 \mathrm{~m}$. The images of the study area are delineated with the help of Survey of India (SOI) toposheets. Thirteen SOI topographical maps of OSM series cover the whole geographic extent of the study area. are used. These maps are at the scale of 1:50,000.

\section{METHODOLOGY}

The study involves the analysis of agricultural and open land use change in Allahabad district. Seven major LULC classes are present in the Allahabad district. For getting LULC information from satellite imagery visual interpretation and digital image processing methods has been used. To recognize and delineate objects in the image various elements of visual image interpretation is used like size, shape, tone, surface and association. On other hand, image classification is the way toward allocating pixels to particular classes. The overall methodology of this work is shown in Figure 2.

\subsection{Extraction of study area administrative boundary} The administrative boundary of the study area is obtained through SOI topographical maps. As these maps are in hardcopy form, therefore conversion of paper maps into digital format is required. For this purpose, scanning of these topographical maps has been done. Subsequent operations are

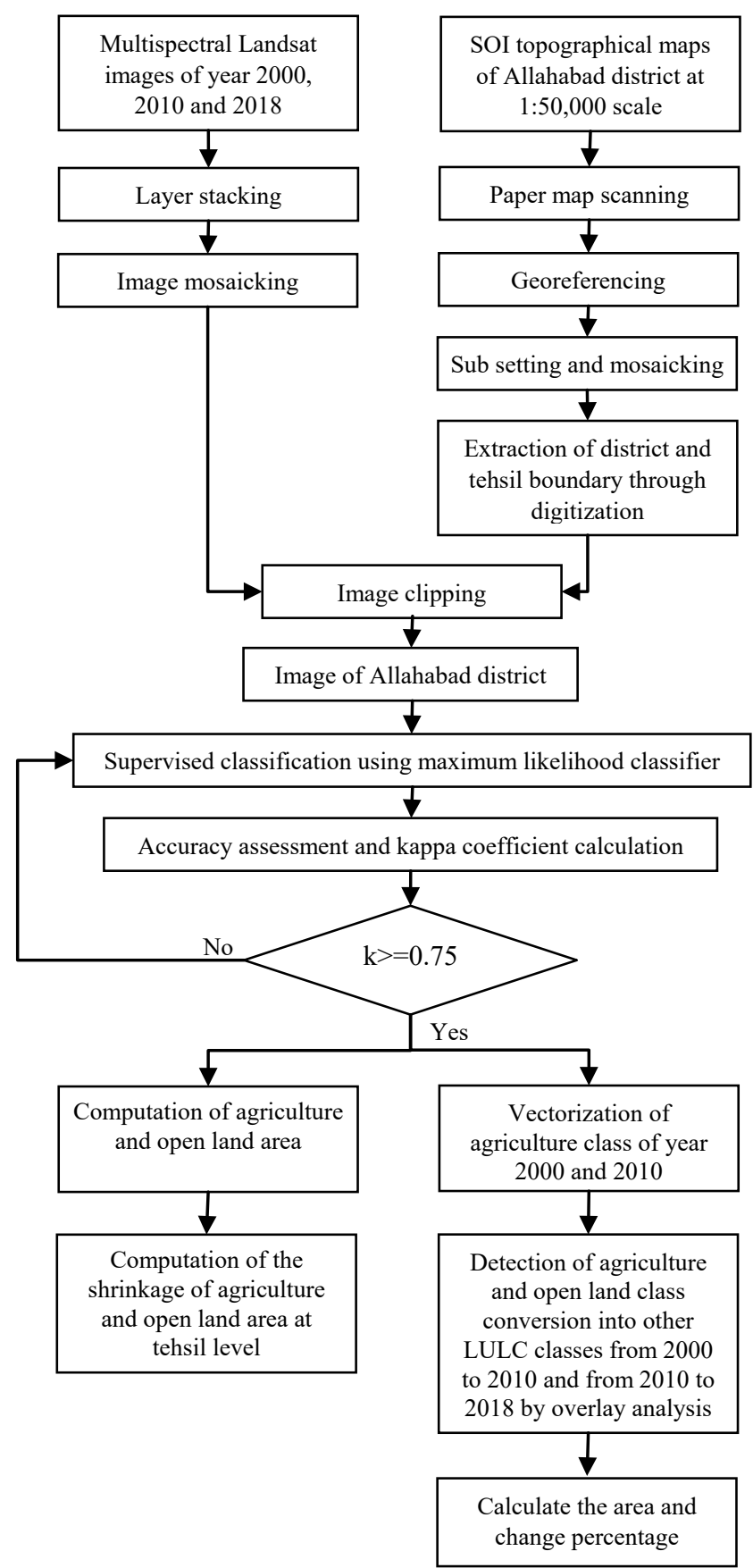

Figure 2. Flowchart of methodology

performed on ArcGIS software. After scanning, georeferencing is performed using affine transformation and nearest neighbourhood interpolation technique. In this datum is set to WGS 84 and projection is set to UTM. Then sub-setting and mosaicking of all maps is done. Map digitization is performed to extract the district and tehsil boundaries. 


\subsection{Image Preparation}

Images of different years of the study area are downloaded from the USGS Landsat archive. As the downloaded multispectral images are in different layers therefore it is necessary to stack them together. Thus layer stacking is performed on all images. Then image is clipped to obtain the image of study area only.

\subsection{Image Classification}

Supervised classification of each of the multispectral image is performed for detecting the changes that have occurred in different time interval. Gaussian maximum likelihood technique is used for supervised classification. The maximum likelihood classifier algorithm relies on the second-order Gaussian probability density function model for each class (Ganasri and Dwarakish, 2015). Training samples are collected with the help of ground truth information. The classes were selected according to the area containing by the particular feature and intensity of acquiring land. After the image classification, accuracy assessment is done on the basis of class by class division. Kappa coefficient $(\mathrm{k})$ is calculated that shows the agreement between the classified data and ground truth. If the value of kappa coefficient is 0.75 or more then the classification is considered as good. Therefore, in this work the next step is proceeded only if the kappa coefficient is 0.75 or more. If the value of kappa coefficient is less than 0.75 then classification procedure is repeated till the coefficient value reaches 0.75 or more.

\subsection{Change detection}

\subsubsection{Agriculture and open land use area calculation}

After classification, the agriculture and open land use area of all the three years i.e. 2000, 2010 and 2018 is calculated. This is performed by pixel based area calculation. In order to see this change at tehsil level, area of agriculture and open land of each tehsil is computed with the help of tehsil boundary shapefile overlay. The loss of agriculture and open land between the consecutive time intervals is computed through comparing the area of temporal classified images.

\subsubsection{Transformation study of agriculture and open land} use area into other LULC classes

Transformation of agriculture and open land into other LULC is also identified for each of the study year. For this agriculture and open land of classified image is vectorised. Then by clipping it from the consecutive year image the transformation is identified. Change table is prepared that gives the information about transformed land into different other LULC classes.

\subsection{LULC mapping}

\section{RESULT AND DISCUSSION}

The LULC map has been generated from the integration of remote sensing data i.e. pixel values with thematic features present on the earth surface. The image is classified into seven LULC classes viz agriculture, built-up, forest, open land, scrubland and water.

Accuracy assessment of this classification is then performed. The ground information or previous knowledge of ground truth for assessment of classified image accuracy is required. This information is collected through SOI topographical maps, Google Earth and field survey. One of the most common ways to express the classification accuracy is by the preparation of classification error matrix which is also known as contingency matrix or confusion matrix. Error matrix comparison is done on the basis of class by class division. In this classification, overall classification accuracy and kappa coefficient are calculated which are shown in Table 1 .

\begin{tabular}{|c|c|c|c|}
\hline S.No & Year & $\begin{array}{c}\text { Overall } \\
\text { accuracy }\end{array}$ & $\begin{array}{c}\text { Kappa } \\
\text { coefficient }\end{array}$ \\
\hline 1 & 2000 & $85 \%$ & 0.82 \\
2 & 2010 & $83 \%$ & 0.79 \\
3 & 2018 & $82 \%$ & 0.78 \\
\hline
\end{tabular}

Table 1. Values of overall accuracy and kappa coefficient

As the value of Kappa coefficient is more than 0.75 in each of the classification, therefore it can be concluded that there is a fine agreement between the classified data and ground truth.

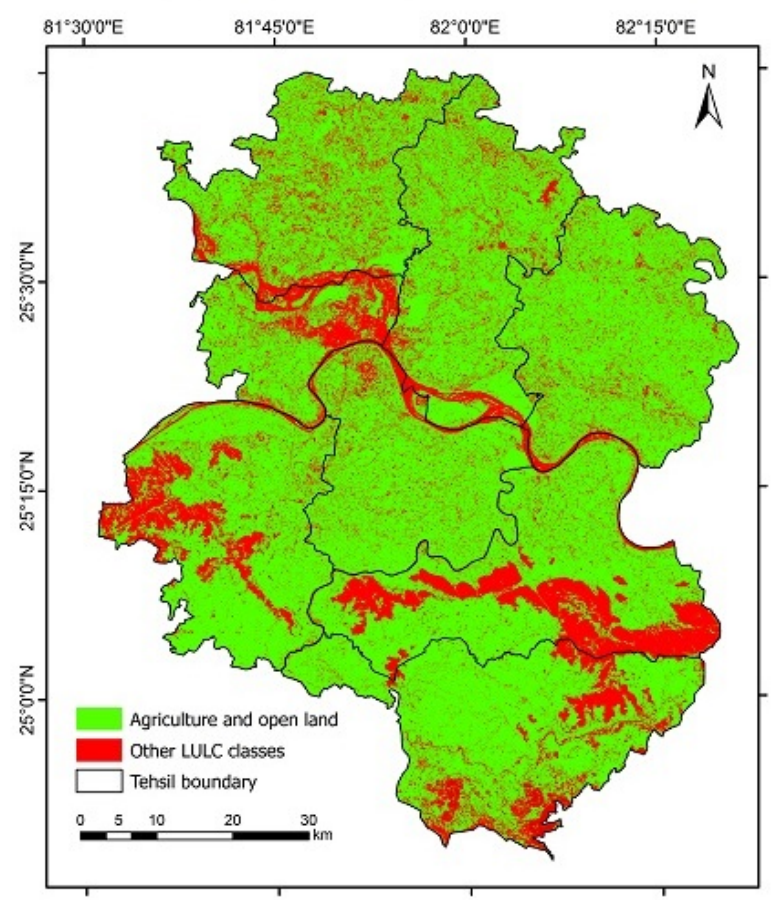

Figure 3. Allahabad district LULC map of year 2000

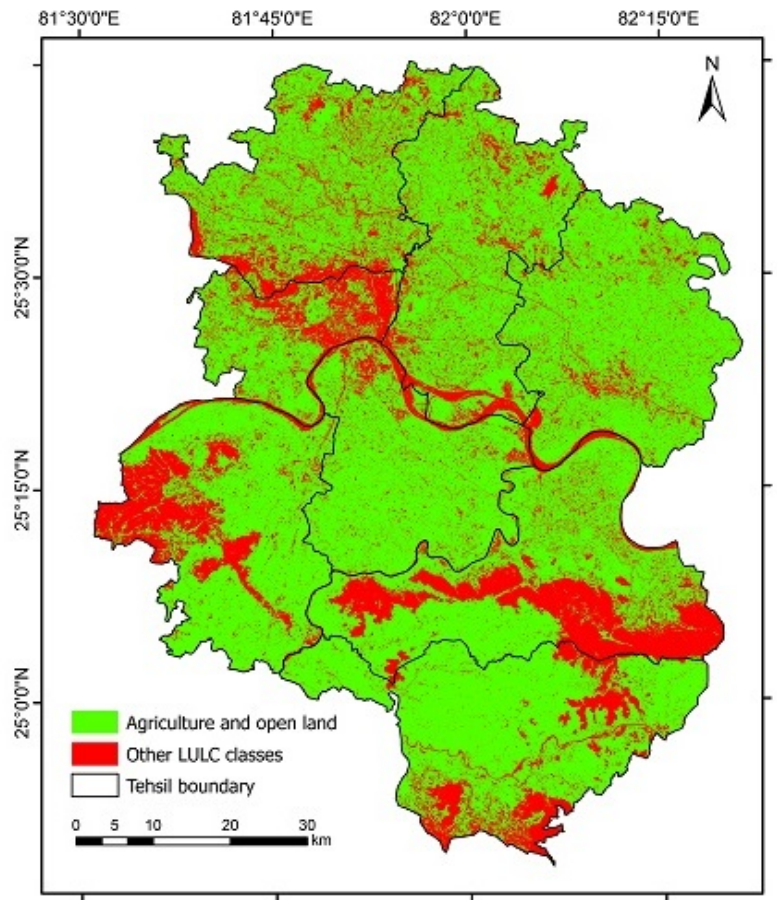


Figure 4. Allahabad district LULC map of year 2010

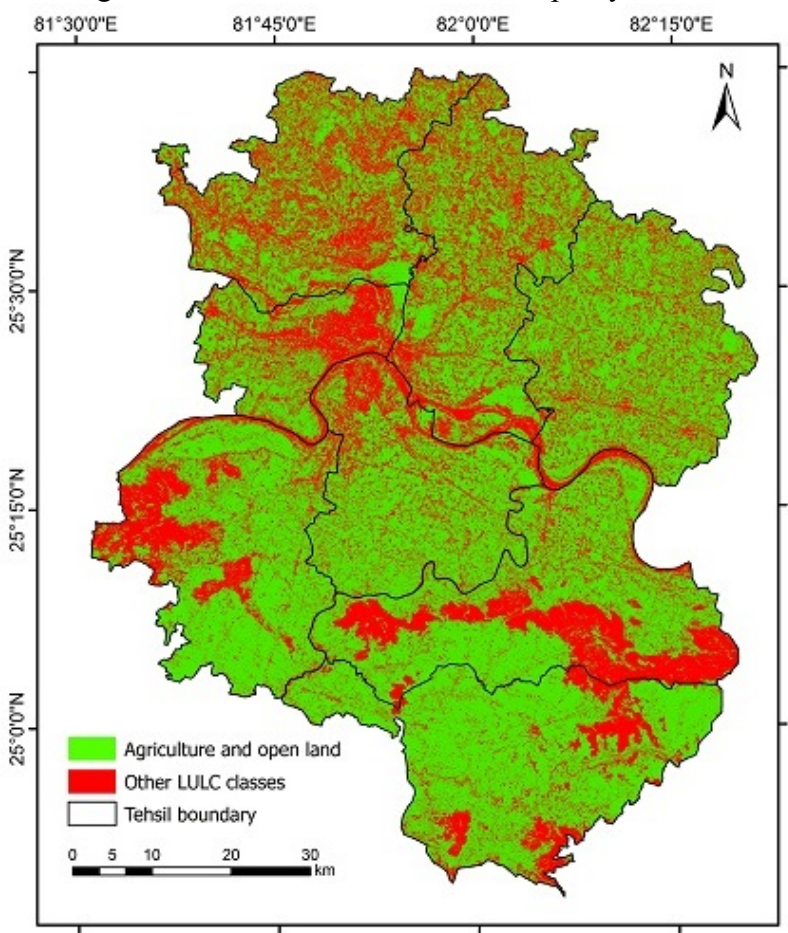

Figure 5. Allahabad district LULC map of year 2018

Figure 3, 4 and 5 are the maps of Allahabad district which are showing two LULC classes of the year 2000, 2010 and 2018 respectively. This map is obtained after supervised classification. In the map, agriculture and open land classes are clubbed together and is shown by the green color. Remaining LULC classes i.e. built-up, forest, scrubland and water are merged together and depicted by the red color. From the maps it can be clearly visualized that the area of green color is continuously shrinking while the red color area is increasing. From this it apparent, that over the years there is a significant loss of agriculture land and the open land where agriculture could be done. This loss is more from 2010 to 2018 as compared from 2000 to 2010.

\subsection{Agriculture and open land use area change}

The computation of different features acreage is performed from the pixel information of the classified image. The area of LULC of different years is shown in Table 2. From the table it is clear that the agriculture and the open land where agriculture can take place are continuously decreasing from the year 2000 to 2018 while the area of other LULC classes is increasing gradually. In year 2000, the area of agriculture and open land was $4202.54 \mathrm{~km}^{2}$ which was reduced to $4097.92 \mathrm{~km}^{2}$ in year 2010. The $104.62 \mathrm{~km}^{2}$ area of agriculture and open land had been transformed into other LULC classes in these ten years. The reduction of agriculture and open land is more severe in next eight years. As per classified image of year 2010, the area of agriculture and open land was $4097.92 \mathrm{~km}^{2}$ which was reduced to $3642.74 \mathrm{~km}^{2}$ in year 2018 . The $455.17 \mathrm{~km}^{2}$ area was converted into other LULC classes.

\begin{tabular}{|c|c|c|c|c|}
\hline S.No & Class & $\begin{array}{c}\text { Area in } \\
2000\end{array}$ & $\begin{array}{c}\text { Area in } \\
2010\end{array}$ & $\begin{array}{c}\text { Area in } \\
2018\end{array}$ \\
\hline 1 & $\begin{array}{l}\text { Agriculture } \\
\text { and open land }\end{array}$ & 4202.53 & 4097.92 & 3642.74 \\
\hline 2 & $\begin{array}{l}\text { Other LULC } \\
\text { classes }\end{array}$ & 1281.02 & 1385.63 & 1840.81 \\
\hline
\end{tabular}

Table 2. Change in features area from year 2000 to 2018. All values of area are in $\mathrm{km}^{2}$.

Further the study is carried out at the tehsil level. For this area of agriculture and open land is calculated for each tehsil. The area change from 2000 to 2010 and from 2010 to 2018 is shown in Table 3 and Table 4 respectively.

\begin{tabular}{|c|l|c|c|c|}
\hline S.No & $\begin{array}{l}\text { Tehsil } \\
\text { Name }\end{array}$ & $\begin{array}{c}\text { Agriculture } \\
\text { and open } \\
\text { land area in } \\
\text { year 2000 }\end{array}$ & $\begin{array}{c}\text { Agriculture } \\
\text { and open } \\
\text { land area in } \\
\text { year 2010 }\end{array}$ & $\begin{array}{c}\text { Agriculture } \\
\text { and open } \\
\text { land area } \\
\text { change }\end{array}$ \\
\hline 1 & Allahabad & 205.10 & 194.14 & 10.96 \\
2 & Bara & 555.76 & 526.38 & 29.38 \\
3 & Handia & 645.82 & 642.74 & 3.08 \\
4 & Karchhana & 487.16 & 496.74 & -9.58 \\
5 & Koraon & 643.43 & 654.40 & -10.98 \\
6 & Meja & 568.76 & 527.54 & 41.21 \\
7 & Phulpur & 580.23 & 562.48 & 17.75 \\
8 & Soraon & 514.90 & 492.17 & 22.73 \\
\hline
\end{tabular}

Table 3. Tehsil wise change in agriculture and open land area from year 2000 to 2010. All values of area are in $\mathrm{km}^{2}$.

\begin{tabular}{|c|l|c|c|c|}
\hline S.No & $\begin{array}{l}\text { Tehsil } \\
\text { Name }\end{array}$ & $\begin{array}{c}\text { Agricultur } \\
\text { e and open } \\
\text { land area } \\
\text { in year } \\
2010\end{array}$ & $\begin{array}{c}\text { Agricultur } \\
\text { e and open } \\
\text { land area } \\
\text { in year } \\
2018\end{array}$ & $\begin{array}{c}\text { Agricultur } \\
\text { e and open } \\
\text { land area } \\
\text { change }\end{array}$ \\
\hline 1 & Allahabad & 194.14 & 178.21 & 15.92 \\
2 & Bara & 526.38 & 510.43 & 15.95 \\
3 & Handia & 642.73 & 543.33 & 99.39 \\
4 & Karchhana & 496.74 & 416.08 & 80.65 \\
5 & Koraon & 654.4 & 639.02 & 15.38 \\
6 & Meja & 527.54 & 516.77 & 10.77 \\
7 & Phulpur & 562.47 & 451.78 & 110.68 \\
8 & Soraon & 492.17 & 385.86 & 106.31 \\
\hline
\end{tabular}

Table 4. Tehsil wise change in agriculture and open land area from year 2010 to 2018 . All values of area are in $\mathrm{km}^{2}$.

From the above data it clear that there is a rapid change in LULC from year 2010 to 2018.All tehsils are affected from this change. The agricultural land loss rate was slow for first decade but from 2010 to 2018 agricultural land loss rate became very rapid. The LULC change in the Soraon and Phulpur tehsils is comparatively more than other tehsils. The less affected tehsils are Koraon followed by Meza and Bara.

\subsection{Transformation of agriculture and open land use area into other LULC classes}

As per the above discussion about the area of different LULC classes, it can be concluded that a large amount area of agriculture and open land is converted into other LULC classes. To study this, the class transformation of the agriculture and open land area from 2000 to 2010 and from 2010 to 2018 is identified. In year 2000 and 2010, the area of agriculture and 
open land was $4202.54 \mathrm{~km}^{2}$ and $4097.92 \mathrm{~km}^{2}$. The $610.49 \mathrm{~km}^{2}$ area out of $4202.54 \mathrm{~km}^{2}$ and $1000 \mathrm{~km}^{2}$ out of $4097.92 \mathrm{~km}^{2}$ is converted into other LULC classes as shown in Table 5. From this table it can be seen that the maximum loss of agriculture and open land is due to increase in built up land and scrubland.

\begin{tabular}{|l|c|c|c|c|}
\hline \multirow{3}{*}{ Class } & \multicolumn{4}{|c|}{$\begin{array}{c}\text { Transformation of agriculture and open land } \\
\text { into other LULC classes }\end{array}$} \\
\cline { 2 - 5 } & From 2000 to 2010 & From 2010 to 2018 \\
\cline { 2 - 5 } & Area & $\%$ & Area & $\%$ \\
\hline Built-up & 152.84 & 3.64 & 799.47 & 19.51 \\
Forest & 35.7 & 0.85 & 92.22 & 2.25 \\
Sand & 53.38 & 1.27 & 13.4 & 0.33 \\
Scrubland & 346.44 & 8.24 & 86.24 & 2.1 \\
Water & 22.13 & 0.53 & 8.66 & 0.21 \\
\hline
\end{tabular}

Table 5. Agriculture and open land transformation into other LULC classes. All values of area are in $\mathrm{km}^{2}$.

\section{CONCLUSIONS}

The aim of this paper is to investigate the agriculture and open land changes occurred in Allahabad district due to rapid urbanisation from year 2000 onwards using satellite image processing. From the analysis it is concluded that the rate of agriculture shrinkage is increasing day by day.

The image classification is performed to create the LULC mapping of the Allahabad district. On the basis of this classification it is concluded that there is a constant reduction in the agriculture and open land use area. As per the GIS based calculations the agriculture and open land use area was $4202.53 \mathrm{~km}^{2}, 4097.92 \mathrm{~km}^{2}$ and $3642.74 \mathrm{~km}^{2}$ in the year 2000 , 2010 and 2018 respectively. The total reduction from 2000 to 2018 is $560 \mathrm{~km}^{2}$. Further this land use shrinkage study is carried out at the tehsil level. From this it is concluded that the reduction of agriculture and open land use area is very high in Soraon and Phulpur tehsils.

As there is a constant shrinkage of agriculture and open land use area, therefore it is required to identify the LULC classes in which they are converting. For this LULC transformation study is carried out. From this it is concluded that most of the agriculture and open land use area is converted into the built up area. This conversion was $3.64 \%$ in between year 2000 to 2010 and $19.51 \%$ for the next eight years.

\section{ACKNOWLEDGEMENTS}

Authors are thankful to Ms. Anamika Yadav, M. Tech. student, GIS Cell, MNNIT Allahabad for her contribution in image preprocessing work.

\section{REFERENCES}

Abdelrahman, M.A.E., Natarajan, A., Hegde, R., 2016. Assessment of land suitability and capability by integrating remote sensing and GIS for agriculture in Chamarajanagar district, Karnataka, India. Egyptian Journal of Remote Sensing and Space Science 19(1), pp. 125-141.

https://doi.org/10.1016/j.ejrs.2016.02.001

Bandyopadhyay, S., Jaiswal, R.K., Hegde, V.S., Jayaraman, V., 2009. Assessment of land suitability potentials for agriculture using a remote sensing and GIS based approach. International Journal of Remote Sensing 30(4), pp. 879-895. https://doi.org/10.1080/01431160802395235
Bhan, S., Behera, U.K., 2014. Conservation agriculture in India - Problems, prospects and policy issues. International soil and water conservation research 2(4), pp. 1-12. https://doi.org/10.1016/S2095-6339(15)30053-8

Brien, K.O., Leichenko, R., Kelkar, U., Venema, H., Aandahl, G., Tompkins, H., Javed, A., Bhadwal, S., Barg, S., Nygaard, L., West, J., 2004. Mapping vulnerability to multiple stressors : climate change and globalization in India. Global Environmental Change 14(4), pp. 303-313. https://doi.org/10.1016/j.gloenvcha.2004.01.001

Census of India (2011), Office of Registrar General of India and Census Commissioner, Government of India.

Fazal, S., 2000. Urban expansion and loss of agricultural land a GIS based study of Saharanpur. Environment \& Urbanization 12, pp. 133-149. https://doi.org/10.1177/0956 24780001200211

Ganasri, B.P., Dwarakish, G.S., 2015. Study of land use / land cover dynamics through classification algorithms for Harangi catchment area , Karnataka State , India. Aquatic Procedia pp. 4, 1413-1420. https://doi.org/10.1016/j.aqpro. 2015.02.183

Ghar, M.A., Shalaby, A., Tateishi, R., 2007. Agricultural land monitoring in the Egyptian Nile delta using Landsat data. International Journal of Environmental Studies 61(6), pp. 3741. https://doi.org/10.1080/0020723042000253866

Gibril, M.B.A., Bakar, S.A., Yao, K., Idrees, O., Pradhan, B., 2016. Fusion of Radarsat-2 and multispectral optical remote sensing data for LULC extraction in a tropical agricultural area. Geocarto International 32(7), pp. 735-748.

https://doi.org/10.1080/10106049.2016.1170893

Hansen, M.C., Loveland, T.R., 2012. A review of large area monitoring of land cover change using Landsat data. Remote Sensing of Environment 122, pp. 66-74.

https://doi.org/10.1016/j.rse.2011.08.024

Hu, T., Yang, J., Li, X., Gong, P., 2016. Mapping Urban Land Use by Using Landsat Images and Open Social Data. Remote Sensing 8(2), pp. 1-18. https://doi.org/10.3390/rs802 0151

Huang, Y., Chen, Z., Yu, T., Huang, X., Gu, X., 2018. Agricultural remote sensing big data: Management and applications. Journal of Integrative Agriculture 17(9), pp. 19151931. https://doi.org/10.1016/S2095-3119(17)618 59-8

Jiang, L., Li, C., Song, B., Li, S., Jiang, L.E.I., Li, C., Song, B.O., Li, S., 2015. Impacts of land use / cover changes on carbon storage in Beijing 1990 - 2010. International Journal of Environmental Studies 72(6), pp. 972-982. https://doi.org/10.1080/00207233.2015.1054140

Kabanda, T.H., 2015. An approach to land capability evaluation for agriculture using remote sensing and GIS in Barberspan, north west province of South Africa. African Journal of Science, Technology, Innovation and Development 7(6), pp. 453-461. https://doi.org/10.1080/204 21338.2015.1096671

Kassawmar, T., Eckert, S., Hurni, K., Zeleke, G., Hurni, H., 2016. Reducing landscape heterogeneity for improved land use and land cover ( LULC ) classification across the large and complex Ethiopian highlands. Geocarto International 33(1), pp. 53-69. https://doi.org/10.1080/1010 6049.2016.1222637 
Lillesand, T.M., Kiefer, R.W., Chipman, J.W., 2004. Remote sensing and Image interpretation, 5th ed. John Wiley \& Sons.

Lin, Y., Wu, P., Hong, N., 2008. The effects of changing the resolution of land-use modeling on simulations of land-use patterns and hydrology for a watershed land-use planning assessment in $\mathrm{Wu}-\mathrm{Tu}$, Taiwan. Landscape and Urban Planning 87, pp. 54-66.

https://doi.org/10.1016/j.landurbplan.2008.04.006

Mendas, A., Delali, A., 2012. Integration of MultiCriteria Decision Analysis in GIS to develop land suitability for agriculture: Application to durum wheat cultivation in the region of Mleta in Algeria. Computers and Electronics in Agriculture 83, pp. 117-126.

https://doi.org/10.1016/j.compag.2012.02.003

Panigrahy, S., Manjunath, K.R., Ray, S.S., 2005. Deriving cropping system performance indices using remote sensing data and GIS. International Journal of Remote Sensing 26(12), pp. 2595-2606. https://doi.org/10.1080/014 31160500114698

Rawat, J.S., Kumar, M., 2015. Monitoring land use / cover change using remote sensing and GIS techniques : A case study of Hawalbagh block, district Almora, Uttarakhand, India. The Egyptian Journal of Remote Sensing and Space Sciences pp. 18, 77-84. https://doi.org/10.1016/ j.ejrs.2015.02.002

Ray, S.S., Dadhwal, V.K., 2001. Estimation of crop evapotranspiration of irrigation command area using remote sensing and GIS. Agricultural Water Management 49(3), pp. 239-249. https://doi.org/10.1016/S0378-3774(0 0)00147-5

Wang, J., Maduako, I.N., 2018. Spatio-te mporal urban growth dynamics of Lagos Metropolitan Region of Nigeria based on Hybrid methods for LULC modeling and prediction European Journal of Remote Sensing 51(1), pp. 251-265.

https://doi.org/10.1080/22797254.2017.1419831

Williams, D.L., Goward, S., Arvidson, T., 2006. Landsat : Yesterday, Today, and Tomorrow. Photogrammetric Engineering \& Remote Sensing 72(10), pp. 1171-1178 